\title{
Population Dynamics of Pratylenchus Brachyurus in Succession of Crops in the Cerrado Biome
}

\author{
Janyne Moura dos Santos ${ }^{1}$, Jéssika Karollyny Ferreira Monteiro Lima ${ }^{2}$, Victor Hugo Moraes ${ }^{1}$, Fernanda \\ Moura dos Santos ${ }^{3}$, Micael José de Almeida ${ }^{4}$, Karine Meira de Abreu ${ }^{1}$, Francisco Vicente Costa Neto ${ }^{5}$, Lorena \\ Cristina Alves Nogueira ${ }^{1}$, Douglas Braga Santos ${ }^{4}$, Franciele de Freitas Silva ${ }^{1}$
}

${ }^{1}$ Postgraduate Program in Agrarian Sciences - Agronomy, Goiano Federal Institute, Rio Verde, Brazil

${ }^{2}$ Instituto Phytus, Planaltina - Distrito Federal, Brazil

${ }^{3}$ Graduated in Biology from the Federal Institute of Goias.

${ }^{4}$ Postgraduate Program in Agrochemistry - Goiano Federal Institute, Rio Verde, Brazil

${ }^{5}$ Academic Biology course, Goiano Federal Institute, Rio Verde, Brazil

Correspondence Author: Janyne Moura dos Santos, Postgraduate Program in Agrarian Sciences - Agronomy, Goiano Federal Institute, Rio Verde, Brazil

Received date: 18 February 2019, Accepted date: 5 April 2019, Online date: 28 April 2019

Copyright: (C) 2019 Janyne Moura dos Santos et al., This is an open-access article distributed under the terms of the Creative Commons Attribution License, which permits unrestricted use, distribution, and reproduction in any medium, provided the original author and source are credited.

\begin{abstract}
The nematodes of the root lesions have caused shocking economic losses in several crops and in several regions of Brazil, mainly in soybean, beans, corn, cotton and pasture. The objective of this work was to analyze the population behavior of $P$. brachyurus in a succession of agricultural crops at points with a higher incidence of nematode during three years of collection. The experiment was conducted in an area of commercial grain cultivation in the municipality of Planaltina - Federal District. Several crops were planted during the three years of collection, being: soy, beans and corn in the year 2014; beans, millet and soybeans in the year 2015 and crotalaria, barley and beans in the year 2016. Five reefs were determined and the collection points were marked through a portable GPS device. The samples were always collected in June of each year. Soil and root samples were collected from the bean crops in 2014, millet in 2015 and barley in 2016. All data were submitted to analysis of variance, and the means separated using the Tukey's test $(\mathrm{P}<\mathbf{0 . 0 5})$. The results obtained here demonstrated that the host nematode culture reinforces the importance of new studies on the population dynamics of nematodes in the soil during the phenological stages of the crop, aiming at finding sustainable alternatives to reduce the population of plant parasites by helping to manage the nematode. soil and increasing crop productivity. The succession of cultures proved to be efficient for population control of $P$. brachyurus. Crotalaria (C. spectabilis) grown in soybean rotation is efficient for the management of $P$. brachyurus infested areas. The cultivated millet showed to be efficient in the succession of crops in areas infested with $P$. brachyurus.
\end{abstract}

Keywords: Crop rotation, crop succession, root lesion nematode.

\section{INTRODUCTION}

The direct and indirect damages caused by nematodes are among the main problems affecting food production (Michereff, 2005). Among the nematodes with the highest occurrence are those of the genus Pratylenchus spp, characterized as migratory endoparasite. It destroys the root system of plants during their penetration and movement, allowing the entry of new hosts such as fungi and bacteria (Dias et al., 2010; Goulart, 2008). In the last few seasons, nematodes of the lesions (Pratylenchus brachyurus) have caused unexpected economic losses in several crops and several regions of Brazil, mainly in soybeans, beans, corn, cotton and pasture (Ribeiro, 2009; Bellé et al., 2017).

Another concern is the multiplication and proper management of P. brachyurus in high soil populations when host plants are cultivated during a long period of the year (Franchini et al., 2014). In Brazil, there are reports of losses of up to 11.93 billion real per year in soybean grain yield, followed by maize and bean crops which together account for a loss of 5.6 billion real in commercial plants infested with P. Brachyurus (Conab, 2016).

Once introduced nematodes into a growing area, their eradication becomes impossible and economically unfeasible. The management of nematodes consists of chemical control with the use of nematicides, cultural practices and biological control. 
Citation: Janyne Moura dos Santos, et al., Population Dynamics of Pratylenchus Brachyurus in Succession of Crops in the Cerrado Biome. Australian Journal of Basic and Applied Sciences, 13(4): 7-10. DOI: 10.22587/ajbas.2019.13.4.2

Among the cultural practices, the use of resistant cultivars including crop rotation or succession of non-host crops is very promising, since it offers the greatest possibilities of success in the control of nematodes (Lima et al., 2015).

Although $P$. brachyurus is widely disseminated in Brazil, there are still few studies on the effects of its parasitism in different cultures. Thus, this study aimed to analyze the population behaviour of $P$. brachyurus in a succession of crops during three years of collection.

\section{MATERIAL AND METHODS}

The experiment was carried out in an area of commercial grain cultivation in the municipality of Planaltina - Federal District, with central geographic coordinates: latitude $15^{\circ} 39^{\prime} 39.5^{\prime} \mathrm{S}$, longitude $47^{\circ} 20^{\prime} 24.2^{\prime \prime} \mathrm{W}$ and an average altitude of $875 \mathrm{~m}$. The area was irrigated by a central pivot irrigation system. The climatic conditions during the collection years varied between 17 and $27^{\circ} \mathrm{C}$.

Several crops were planted during the three years of collection, being: soy, beans and corn in the year 2014; beans, millet and soya in the year 2015 and crotalaria, barley and beans in the year 2016. The study area was chosen due to the history of the presence of $P$. brachyurus in the harvest of 2013/2014. The crop sequence was a standard in which the farmer had employed his property.

Collection points were determined and tagged using a portable GPS device (Garmin eTrex® 30, Garmin International, Olathe, KS). The collections were always carried out in June of each year, and soil and root samples were collected from the bean crops in 2014, millet in 2015 and barley in 2016.

Table 1: Geographic coordinates of the collection points of nematode samples

\begin{tabular}{|c|c|c|c|}
\hline Points & Latitude & Longitude & Altitude \\
\hline 1 & $15^{\circ} 39^{\prime} 47.0^{\prime \prime}$ & $47^{\circ} 20^{\prime} 20,6^{\prime \prime}$ & 882 \\
\hline 2 & $15^{\circ} 39^{\prime} 46,8^{\prime \prime}$ & $47^{\circ} 20^{\prime} 20,5^{\prime \prime}$ & 884 \\
\hline 3 & $15^{\circ} 39^{\prime} 46,6^{\prime \prime}$ & $47^{\circ} 20^{\prime} 20,5^{\prime \prime}$ & 883 \\
\hline 4 & $15^{\circ} 39^{\prime} 46,2^{\prime \prime}$ & $47^{\circ} 20^{\prime} 20,6^{\prime \prime}$ & 882 \\
\hline 5 & $15^{\circ} 39^{\prime} 45,5^{\prime \prime}$ & $47^{\circ} 20^{\prime} 20,2^{\prime \prime}$ & 883 \\
\hline
\end{tabular}

Due to the autodissemination of $P$. brachyurus being relatively small, the collection points were in the center of the reefs, resulting in five reefs. Samples of soil $(500 \mathrm{~g})$ and root $(50 \mathrm{~g})$ were collected at each point (Table 1), taken at depths of 25 to 30 $\mathrm{cm}$. Each collection point was the result of five soil samples and 15 plants with different injury symptoms. The samples were homogenized and stored in plastic bags. After collection, the material sampled was taken to the Phytus Institute of the Federal District for extraction, identification and quantification of P. brachyurus, using the method described by Jenkins (1964) for soil and Coolen \& D'Herde (1972) for root. In the extraction, an aliquot of $200 \mathrm{~cm}^{3}$ of soil and $10 \mathrm{~g}$ of roots were used. The nematodes were quantified and identified under an optical microscope, using the Peters counting chamber (Southey, 1970).

Statistical analysis: All data were tabulated and submitted to analysis of variance and the means were separated by the Tukey test $(\mathrm{P}<0.05)$ by the Sisvar (Universidade Federal de Lavras, Lavras, Minas Gerais) computational program.

\section{RESULTS AND DISCUSSION}

An increasing number of $P$. brachyurus have been observed that have multiplied throughout host crops planted in the area. In the year 2016 there was a decrease in the population of this nematode which may be due to the influence of non-host crops that were planted in the year 2016 as shown in Table 2. The specimens of P. brachyurus were found to be found in small amounts or no amount. The area that was evaluated may have been cultivated by non-host plants to the nematode prior to the first evaluations, associating with the low initial population.

Table 2: Result of the count of the nematodes present in $200 \mathrm{~cm}^{3}$ soil and 5 grams of root in a central pivot cultivation area in the Central Plateau region, Planaltina - Federal District, during three years of sampling.

\begin{tabular}{|c|c|c|c|c|c|c|c|c|c|c|c|}
\hline \multirow{2}{*}{ Year } & \multirow{2}{*}{ Variable } & \multicolumn{2}{|c|}{ Point 1} & \multicolumn{2}{|c|}{ Point 2} & \multicolumn{2}{|c|}{ Point 3} & \multicolumn{2}{|c|}{ Point 4} & \multicolumn{2}{|c|}{ Point 5} \\
\hline & & Soil & Root & Soil & Root & Soil & Root & Soil & Root & Soil & Root \\
\hline \multirow[b]{2}{*}{2014} & P. brachyurus & 0 & 433 & 0 & 450 & 20 & 383 & 0 & 281 & 20 & 350 \\
\hline & $\begin{array}{c}\text { P. brachyurus } \\
\text { eggs }\end{array}$ & 40 & 683 & 40 & 266 & 100 & 270 & 20 & 300 & 60 & 450 \\
\hline \multirow[b]{2}{*}{2015} & P. brachyurus & 80 & 1360 & 20 & 10430 & 0 & 100 & 40 & 1160 & 40 & 830 \\
\hline & $\begin{array}{c}\text { P. brachyurus } \\
\text { eggs }\end{array}$ & 30 & 500 & 0 & 4060 & 40 & 130 & 10 & 760 & 10 & 330 \\
\hline \multirow[b]{2}{*}{2016} & P. brachyurus & 0 & 106 & 0 & 226 & 0 & 75 & 0 & 65 & 0 & 76 \\
\hline & $\begin{array}{c}\text { P. brachyurus } \\
\text { eggs }\end{array}$ & 0 & 45 & 0 & 53 & 0 & 19 & 0 & 0 & 0 & 0 \\
\hline
\end{tabular}


The reflex symptoms in the years 2014 and 2015 caused in the plants of the foci of infestation presented typical symptoms caused by $P$. brachyurus, including the uneven growth of the plants, necrotic roots, dark and less secondary roots. These damages were evident in the two years of collection as shown in Figure 1.

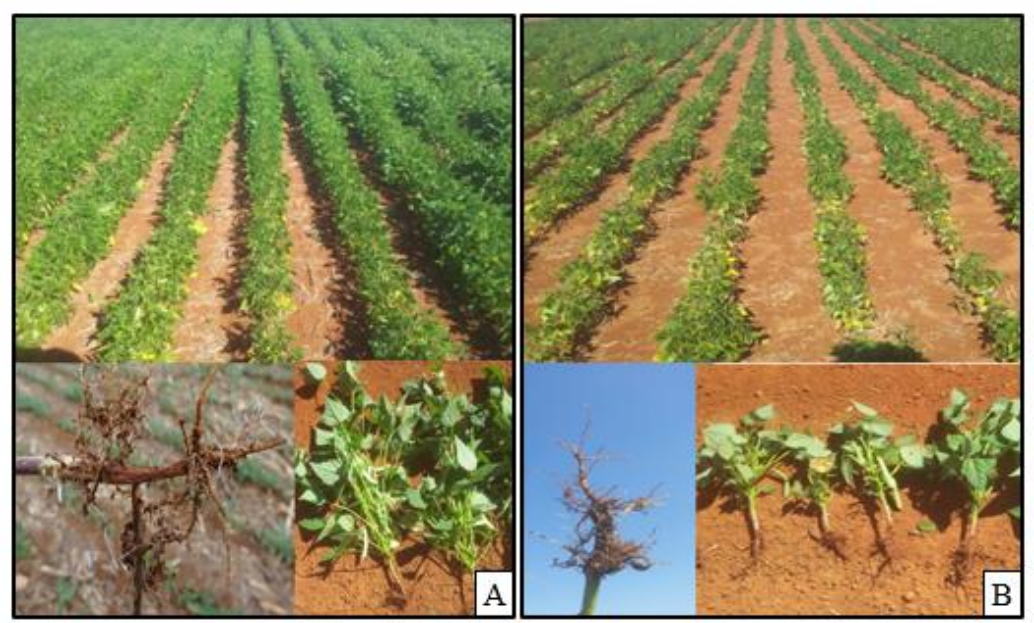

Figure 1: Bean culture in different years: A- bean culture in 2014; B - bean culture in 2015.

When comparing the average population of $P$. brachyurus, the results showed a gradual increase of the population of its population between the years 2014 and 2015 and a decrease of the population in the year 2016 due to the crops planted in that year. In figure 2 the results were significant between the average of the three years of collection. To understand the great increase in the population of $P$. brachyurus, we observe the history of crops planted in those respective years. Cultures susceptible to the nematode were planted, thus justifying the increase in reproduction by a large amount of nutrients in the area. In this way, it was suggested the adoption of crop rotation being planted non-host strains to the $P$. brachyurus nematode. Due to the population increase of the nematode, the cultivation of millet "ADR 300" and Crotalaria spectabilis (Crotalaria spectabilis) were planted after soybean planting, which are recommended crops due to their efficiency in nematode control. It is also observed that for all the years of collection, that there was a greater population of $P$. brachyurus in the soil than in the root (nematoid and egg). As the area management with crop rotation was properly used, there was a significant reduction of the nematodes and eggs present in the soil, being able to find high populations of nematodes and eggs only in the root in the samplings of 2016.

Figure 2 - Population of $P$. brachyurus (specimens and eggs) in the soil and root of the three years of sampling.

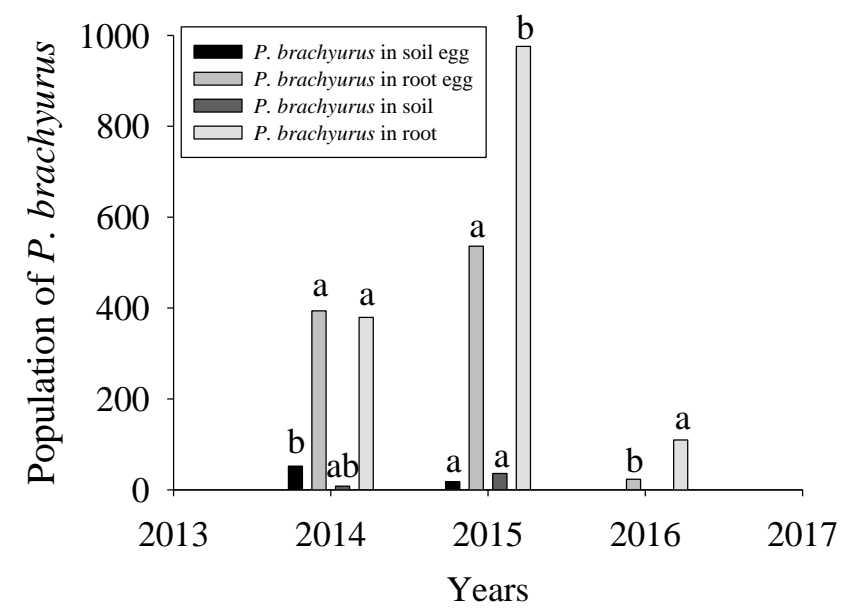

* The letters compare differences of the population of $P$. brachyurus during sampling times, at the 0.05 level of probability by the Tukey test.

The results emphasize the importance of crop rotation in nematode control. According to Silva (2018), the period of rotation with antagonistic or non-host plants makes nematode reproduction difficult and allows natural mortality factors to reduce their population. Thus, the succession of the crops made by the producer of this area proved to be efficient in 2016. Although soil population density is not the best way of estimating the development of the nematode in question (Galbieri and Asmus, 2016), it can be observed that the year cultivated with crotalaria were those that maintained the lowest population densities of $P$. brachyurus throughout the years of sampling.

The resistance of Crotalaria, mainly of C. spectabilis, and of pearl millet to P. brachyurus have been efficient in experiments conducted in greenhouse (Inomoto and Asmus, 2010; Ribeiro et al., 2007; Inomoto et al., 2006). The effect of crotalaria where 
Citation: Janyne Moura dos Santos, et al., Population Dynamics of Pratylenchus Brachyurus in Succession of Crops in the Cerrado Biome. Australian Journal of Basic and Applied Sciences, 13(4): 7-10. DOI: 10.22587/ajbas.2019.13.4.2

higher soil cover is observed, greater amount of green mass and lower occurrence of chlorotic plants compared to previous crops (Silva, 2018). In the case of millet, resistance to the nematode is inconsistent and varies according to the cultivar and the reaction period (Borges, 2009; Inomoto and Asmus, 2010).

The results obtained here demonstrate that the planted host crop of the nematodes belonging to this group is dominant in the soil, which reinforces the importance of further studies on the population dynamics of nematodes in the soil during the phenological phases of the crop, aiming to find sustainable alternatives to decrease the population of plant parasites assisting in soil management and increasing crop productivity. The succession of cultures proved to be efficient for population control of $P$. brachyurus. Crotalaria (C. spectabilis) grown in soybean rotation is efficient for the management of $P$. brachyurus infested areas. The cultivated millet showed to be efficient within the succession of crops in areas infested with P. brachyurus.

\section{REFERENCES}

Bellé, C., Kuhn, P. R., Kaspary, T. E., and Schmitt, J. 2017. Reação de cultivares de soja a Pratylenchus brachyurus. Revista Agrarian, 10(36): 136-140.

Borges, D. C. 2009. Reação de culturas de cobertura utilizadas no sistema de plantio direto ao nematoide das lesões Pratylenchus brachyurus e ao nematoide das galhas, Meloidogyne incógnita. Dissertação (Mestrado) - Escola Superior de Agricultura Luiz de Queiroz, USP, 44 p. 10.

Coolen, W.A., C.J. D’ Herde. 1972. A method for the quantitative extraction of nematodes from plant tissue. Belgium: Min. Agric. Res. Adm. State Centre, Ghent - Belgium, 77 p.

Conab - Acompanhamento da safra brasileira de grãos - Segundo levantamento - novembro 2016.

Dias, W. P., Asmus, G. L., Silva, J. F. V., Garcia, A., Carneiro, G. E. S. 2010. Soja: doenças radiculares e de hastes e interrelações com o manejo do solo e da cultura. Londrina: Embrapa Soja, 173-206.

Franchini, J. C., Debiasi, H., Dias, W. P., Ramos Junior, E. U., Silva, J. F. V. Perda de produtividade da soja em área infestada por nematoide das lesões radiculares na região médio norte do Mato Grosso. 2014. Agricultura de precisão: resultados de um novo olhar. São Carlos: Embrapa Instrumentação, 274 - 278.

Galbieri, R., and Asmus, G. L. 2016. Principais espécies de nematoides do algodoeiro no Brasil. Nematoides fitoparasitas do agodoeiro nos cerrados brasileiros: Biologia e medidas de controle. Cuiabá: IMAmt, 11-36.

Goulart, A. M. C. 2008. Aspectos Gerais sobre nematoides das lesões radiculares (gênero Pratylenchus). Planaltina, DF: Embrapa Cerrrados, $30 \mathrm{p}$.

Inomoto, M. M., and Asmus, G. L. 2010. Host status of graminaceous cover crops for Pratylenchus brachyurus. Plant Disease, 98(8): 1022-1025.

Inomoto, M. M., Motta, L. C. C., Beluti, D. B., Machado, A. C. Z. 2006. Reação de seis adubos verdes a Meloidogyne javanica e Pratylenchus brachyurus. Nematologia Brasileira, 30(1): 39-44.

Jenkins, W.R. 1964. A rapid centrifugal-flotation technique for separating nematodes from soil. Plant Disease Reporter, 48: 692p.

Lima, F. S. D. O, G. R. D., Santos, S. R., Nogueira, P. R. R. D., and Correa, V. R. 2015. Dinâmica

populacional do nematoide das lesões radiculares Pratylenchus brachyurus em campos de soja no Tocantins e

seu efeito na produção. Nematropica 45:170-177.

Michereff, S. J., Andrade, D. E. G. T., Menezes, M. 2005. Ecologia e Manejo de Patógenos Radiculares em Solos Tropicais. Recife: UFRPE.

Ribeiro, N. R., Dias, W. P., Homechin, M., Silva, J. F. V., Francisco, A. 2007. Reação de genótipos de soja a Pratylenchus brachyurus. Nematologia Brasileira, 31(2): 157-158.

Ribeiro, N.R. 2009. Avaliação de espécies vegetais e cultivares de soja para a composição de esquemas de rotação ou sucessão de culturas para o manejo de Pratylenchus brachyurus. Tese (Doutorado em Agronomia) - Universidade Estadual de Londrina, Londrina, $56 \mathrm{p}$.

Silva, R. A., Nunes, N. A., Santos, T. F. S., and Iwano, F. K. 2018. Efeito da rotação e sucessão de culturas no manejo de nematoides da soja em área arenosa. Nematropica 48:198-206.

Southey, J. F. 1970. Laboratory methods for work with plant and soil nematodes. London: Ministry of Agriculture Fisheries and Food 5: 148p. 